\title{
Determination of the Dependence of the Plant Growth Characteristics on the Concentration of Petrochemicals in the Soil
}

\author{
Larysa Cherniak ${ }^{1 *}$, Oleksandr Mikhyeyev'1, Svitlana Madzhd', Lapan Oksana', \\ Dmytrukha Tetyana', Petrusenko Valentyna' ${ }^{1}$
}

1 Department of ecology, National Aviation University, Kyiv, 03058, Ukraine

* Corresponding author's e-mail: specially@ukr.net

\begin{abstract}
The peculiarities of sanitary and hygienic rationing of the oil products content in environmental components were analyzed. It was established that the general ecological situation in our country and abroad is unsatisfactory and the issue of finding modern methods of standardizing the quality of environmental components, which would cover the indicators and criteria of their composition and properties, is becoming increasingly urgent. Together, it would ensure ecologically sustainable development of the biosphere in all hierarchical levels of its organization. It was established that such an assessment system does not exist today and therefore, there is no generally accepted universal method for assessing the quality of the environmental components. For this purpose, it is necessary to develop a methodology, in particular a method of biotesting, which will provide a generalized qualitative assessment of the ecological state of the environment, without being based on the quantitative characteristics of the MPC. The possibility of applying a new method of phytotesting of soil that was artificially contaminated with different types of petrochemicals in different concentrations per unit volume of soil using flax seedlings (Linum usitatissimum L.) was investigated. The growth characteristics of the test plants grown on artificially contaminated soil with petroleum products were presented. In the course of research, the possibility of studying the effect of petrochemicals on plants directly in artificially contaminated soil was confirmed. On the basis of the analysis of the obtained results, it was found that when the soil is contaminated with oil products, the aviation fuel has a greater impact on the shoots, whereas gasoline and diesel fuel have a lower impact on the roots in lower concentrations. At higher concentrations, their depressant effect is almost equal.
\end{abstract}

Keywords: bio tests, petroleum products, soil contamination, chemical pollution.

\section{INTRODUCTION}

The constant growth of the anthropogenic impact on the environment has led to the need to improve the system of ecological assessment of the environmental components [Isaienko, 2019, Madzhd, 2017, Mylarshchikov, 2012], as the current sanitary and hygienic regulations in Ukraine are not an adequate criterion for assessing the ecological status of environmental components [Anpilova, 2020, Han, 2016, Kozulia, 2017].

The requirements established in the state normative documents contradict the physiological criteria; they are based on an anthropocentric approach, despite the fact that a man is one of the most resistant species to the influence of external factors [Arystarkhova, 2017]. The main disadvantage of ecological regulation is that most of the rules do not take into account the laws of ecosystems and mechanisms for their self-restoration. The existing system of sanitary and hygienic rationing is costly and inefficient; it is based on the use of quantitative characteristics - maximum permissible concentrations (MPC) of pollutants. This system of standardization according to the MPC is a subjective method of control, as it is based on the comparison of the actual concentrations with the maximum allowed; this, for a long time in the world it has been subject to reasoned criticism. The definition of individual factors of influence does not give a holistic view of the synergistic effect of simultaneously acting pollutants 
on the environment and, accordingly, does not take into account the intensity of the structural and functional changes in the processes occurring in them [Madzhd, 2013]. In addition, at the stage of development of environmental standards, territorial differentiation and specific characteristics of regions are not taken into account.

Taking these shortcomings of environmental regulation into account, environmental scientists are constantly developing new methods for assessing the state of the environment. The disadvantages of many existing methods of assessing the state of the environment are that they are based (directly or indirectly) on the transformation of quantitative indicators into qualitative indices of ecological status. Numerous methods are created using transformation methods, which are united by the field of research of the state of the environment and by the type of nature management [Hussain, 2019, Madzhd, 2019, Nakamura, 2011, Radomska, 2020, Udod, 2017]. The analysis of the shortcomings of the existing environmental regulation methods and the effectiveness of the developed integrated indices [Iatsyk, 2007, Lim, 2016, Mylarshchikov, 2012, Sukhariev, 2016] showed that they are all based on the use of only quantitative characteristics (MPC) of pollutants. Modern research is mainly focused on compliance with standards to ensure the necessary requirements for continuous use of nature in the interests of human society. Unfortunately, the assessment of structural and functional changes in the interests of the biosphere - environmental indicators of air, surface water, soil - is not given attention at the moment [Danilov-Danilian, 2014, Obyhod, 2016., Radomska, 2018].

The imperfect system of sanitary and hygienic rationing has led to the fact that the general ecological situation in our country and abroad is unsatisfactory and the question of finding more adequate methods of rationing the quality of environmental components is becoming increasingly urgent, which would include the indicators and criteria of their composition and properties. Altogether, it would solve the problems caused by thoughtless, predatory, irrational use of nature and would ensure ecologically balanced development of the biosphere of all hierarchical levels of the organization [Hussain, 2019, Shevchyk, 2017].

Nowadays, there is no generally accepted universal method for assessing the quality of the environment. Our proposed method will allow obtaining a generalized qualitative assessment of the ecological state of the environment without being based only on the quantitative characteristics of the MPC.

The modern development of the transport sector is accompanied by a constant increase in the negative impact on the environment. In particular, this applies to the impact of storage and refueling of vehicles. Therefore, there is a need to assess the ecological status of soils at these facilities and to assess the environmental risks associated with the activities of these facilities. Taking into consideration the fact that despite the danger of petroleum products for all components of the environment, there are currently no established maximum concentration limits for the content of petroleum products in the environment. MPCs are set only for certain hydrocarbons that are part of modern fuels. This complicates the assessment of the consequences of environmental pollution by petroleum products of different brands, because petroleum products are mixtures of an average of about 200 different carbohydrates.

The aim of our study was to use a new method of phytotesting of soil conditions, in studying soil which was artificially contaminated with different types of petroleum products in different concentrations using flax seedlings (Linum usitatissimum L.).

\section{MATERIAL AND METHODS}

Materials and methods: soil samples (soil mixture for seedlings $\mathrm{pH}$ 5.0-7.0), flax seeds (Linum usitatissimum L.), thermostat for germination of seeds, tanks, oil fuels: A-95 grade gasoline, TS-1 aviation kerosene, diesel fuel (DF).

Seed germination method: 13 air-dry soil samples with a volume of $400 \mathrm{dm}^{3}$ were prepared for seed germination in the containers measuring $12.0 \times 21.0 \times 1.5 \mathrm{~cm}$.

The soil samples were artificially contaminated by adding a certain number of different brands of petroleum products in extremes to the established approximate permissible concentration (APC). Namely:

- control test without the introduction of petroleum products;

- $0.2 \mathrm{~g} / \mathrm{kg}$ of A-95 grade automobile gasoline (1 APC);

- $2 \mathrm{~g} / \mathrm{kg}$ of A-95 grade gasoline (10 APC);

- $20 \mathrm{~g} / \mathrm{kg}$ of A-95 grade motor gasoline (100 APC); 
- $200 \mathrm{~g} / \mathrm{kg}$ of A-95 grade motor gasoline 5 (1000 APC);

- $0.2 \mathrm{~g} / \mathrm{kg}$ of TS-1 grade aviation kerosene (1 APC);

- $2 \mathrm{~g} / \mathrm{kg}$ of TS-1 grade aviation kerosene (10 APC);

- $20 \mathrm{~g} / \mathrm{kg}$ of TS-1 grade aviation kerosene (100 APC);

- $200 \mathrm{~g} / \mathrm{kg}$ of TS-1 grade aviation kerosene (1000 APC);

- $0.2 \mathrm{~g} / \mathrm{kg}$ of diesel fuel (1 APC);

- $2 \mathrm{~g} / \mathrm{kg}$ of diesel fuel (10 APC);

- $20 \mathrm{~g} / \mathrm{kg}$ of diesel fuel (100 APC);

- $200 \mathrm{~g} / \mathrm{kg}$ of diesel fuel (1000 APC).

The soil was moistened by adding $100 \mathrm{ml}$ of distilled water to each experimental variant for germination. Approximately 300 flax seeds were situated on the soil surface in each germination tray (Fig. 1). The plants were placed in a thermostat under constant lighting with an intensity of $2.2 \mathrm{kLk}$ and a temperature of $25^{\circ} \mathrm{C}$.

The method of determining the growth characteristics of plants was implemented as following: on the 3rd day of seed germination, 72 seedlings were selected from each variant of the experiment; determined the length of roots and shoots of plants; the plants grown without the addition of petroleum products served as controls.

\section{RESULTS AND DISCUSSION}

The appearance and length of 3-day and 6-day seedlings grown on soil with different concentrations of artificial pollution are presented in Table 1.

The results of the influence of different types of fuels on the length of the root and shoots of 3-day flax seedlings are presented in Figs. 2 and 3. It can be seen that low concentrations of gasoline and aviation kerosene stimulate the root growth, and gasoline at all applied concentrations adversely affects the root system. It is obvious that the concentration of $1000 \mathrm{OKD}$ is above the threshold in terms of inhibition of the growth rates for all used fuels (Fig. 2-3). Stimulation of the shoot growth was observed for motor gasoline and aviation kerosene. Diesel fuel had a negative effect at all applied concentrations.

While analyzing the results of measuring the growth parameters of six-day flax seedlings, it was found (Fig. 4) that the root system practically does not feel the action of petroleum hydrocarbons at the employed concentrations, and even see some stimulating (hormesis) effect can be seen. The toxic effects of gasoline and diesel fuel were compared with previous results of studies of growth characteristics of three-day seedlings.

Regarding the plant shoots (Fig. 5), the results indicate a lower level of influence, or indirect influence through the root system. For example, for diesel fuel, even a hormesis effect was observed. However, based on the reaction of the root to contamination by aviation kerosene, it can be assumed that the stimulation of shoots is the result of direct action of the contaminant. In the case of diesel contamination, most likely, there was an indirect effect on the shoots starting from 100 APC of oil content in the studied soil samples, and starting from $1 \mathrm{APC}$ - direct action.

It is known that the studied fuel samples include light fractions of oil, which contain varying amounts of simpler low molecular weight hydrocarbons in their composition, in particular: methane (alkanes), naphthenic (cycloparaffins) and aromatic. Among the studied fuel samples, hydrocarbons that are part of motor gasoline are the most volatile, mobile and toxic. They are able to migrate along the soil profile and aquifers. Methane hydrocarbons of light fraction have a toxic

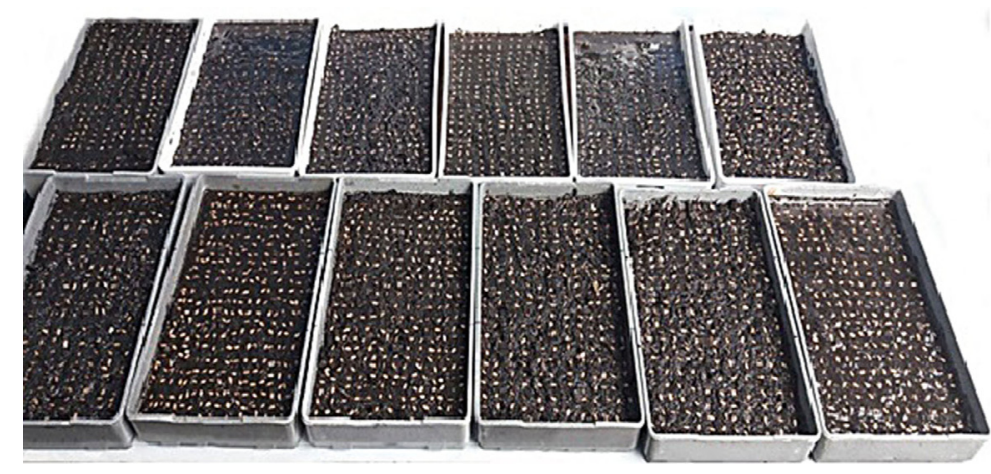

Figure 1. Prepared soil samples with sown flax seeds 
Table 1. Appearance and length of the test plants grown on artificially contaminated soil, 3 and 6 days of seedlings

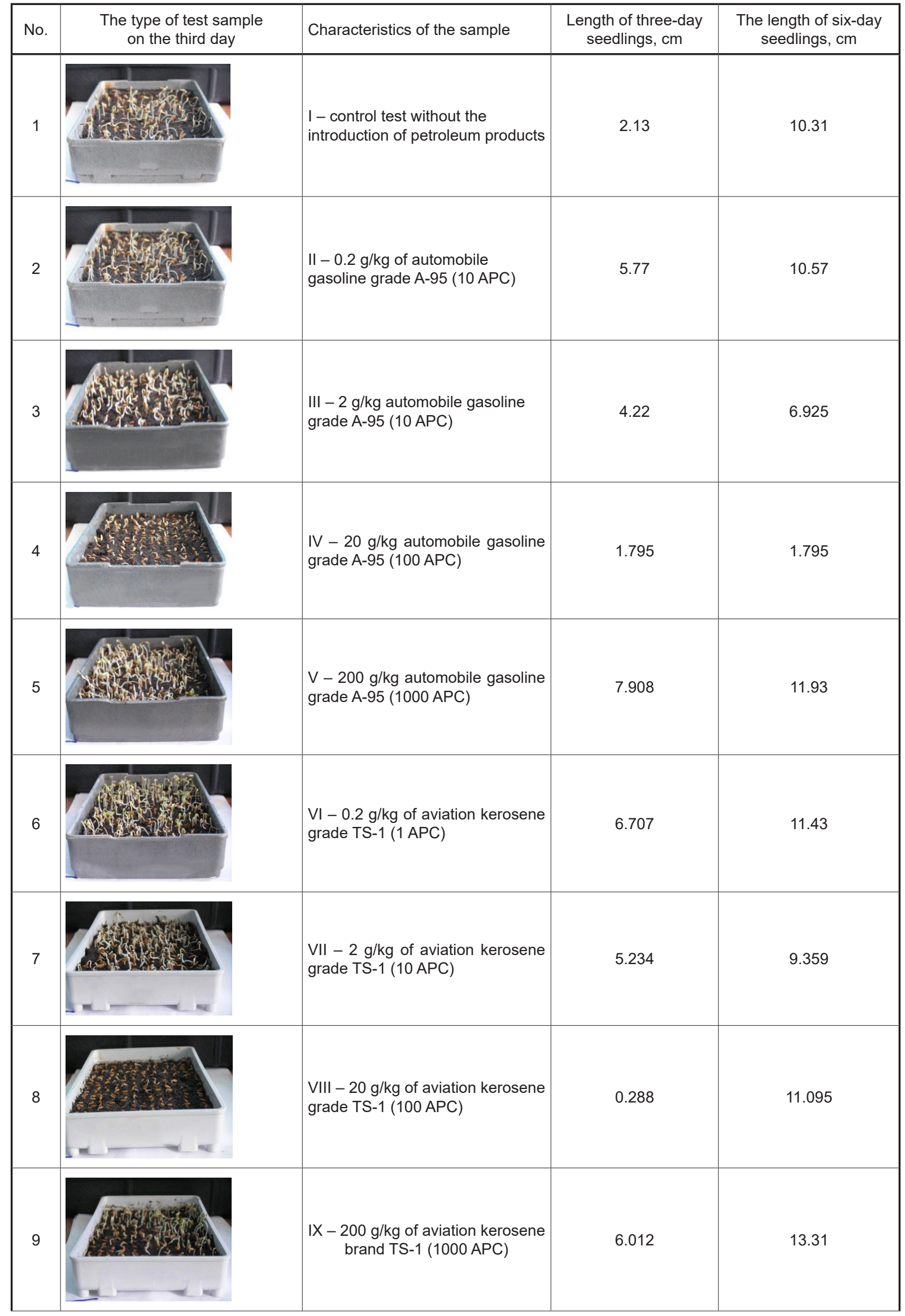


Table 1. cont.

\begin{tabular}{|c|c|c|c|c|}
\hline No. & $\begin{array}{c}\text { The type of test sample } \\
\text { on the third day }\end{array}$ & Characteristics of the sample & $\begin{array}{l}\text { Length of three-day } \\
\text { seedlings, } \mathrm{cm}\end{array}$ & $\begin{array}{l}\text { The length of six-day } \\
\text { seedlings, } \mathrm{cm}\end{array}$ \\
\hline 10 & & $\begin{array}{l}X-0.2 \mathrm{~g} / \mathrm{kg} \text { of Diesel fuel } \\
(1 \mathrm{APC})\end{array}$ & 4.42 & 12.37 \\
\hline 11 & & $\begin{array}{l}X \mathrm{X}-2 \mathrm{~g} / \mathrm{kg} \text { of Diesel fuel } \\
(10 \mathrm{APC})\end{array}$ & 3.719 & 10.99 \\
\hline 12 & & $\begin{array}{l}\text { XII }-20 \mathrm{~g} / \mathrm{kg} \text { of Diesel fuel } \\
(100 \mathrm{APC})\end{array}$ & 0.953 & 0.953 \\
\hline 13 & & $\begin{array}{l}\text { XIII }-200 \mathrm{~g} / \mathrm{kg} \text { of Diesel fuel } \\
(1000 \mathrm{APC})\end{array}$ & 5.8 & 5.8 \\
\hline
\end{tabular}

Table 2. Comparative growth characteristics of the test plants grown on oil-contaminated soil, 3 and 6 days of seedlings with control

\begin{tabular}{|c|c|c|}
\hline Soil sample & $\begin{array}{l}\text { The length of three-day } \\
\text { seedlings for control, } \%\end{array}$ & $\begin{array}{l}\text { The length of six-day } \\
\text { seedlings for control, \% }\end{array}$ \\
\hline I - control test without the introduction of petroleum products & 100 & 100 \\
\hline II $-0.2 \mathrm{~g} / \mathrm{kg}$ of automobile gasoline grade A-95 (10 APC) & 270 & 103 \\
\hline III - 2 g/kg of automobile gasoline grade A-95 (10 APC) & 198 & 67 \\
\hline IV - $20 \mathrm{~g} / \mathrm{kg}$ of automobile gasoline grade A-95 (100 APC) & 84.3 & 17.4 \\
\hline V - $200 \mathrm{~g} / \mathrm{kg}$ of automobile gasoline grade A-95 (1000 APC) & 371 & 116 \\
\hline $\mathrm{VI}-0.2 \mathrm{~g} / \mathrm{kg}$ of aviation kerosene grade TS-1 (1 APC) & 314 & 111 \\
\hline VII $-2 \mathrm{~g} / \mathrm{kg}$ of aviation kerosene grade TS-1 (10 APC) & 246 & 91 \\
\hline VIII - $20 \mathrm{~g} / \mathrm{kg}$ of aviation kerosene grade TS-1 (100 APC) & 13.5 & 108 \\
\hline IX - $200 \mathrm{~g} / \mathrm{kg}$ of aviation kerosene grade TS-1 (1000 APC) & 282 & 129 \\
\hline $\mathrm{X}-0.2 \mathrm{~g} / \mathrm{kg}$ of Diesel fuel (1 APC) & 208 & 120 \\
\hline$X I-2 \mathrm{~g} / \mathrm{kg}$ of Diesel fuel (10 APC) & 175 & 107 \\
\hline XII - $20 \mathrm{~g} / \mathrm{kg}$ of Diesel fuel (100 APC) & 45 & 9.25 \\
\hline XIII - $200 \mathrm{~g} / \mathrm{kg}$ of Diesel fuel (1000 APC) & 272 & 56 \\
\hline
\end{tabular}




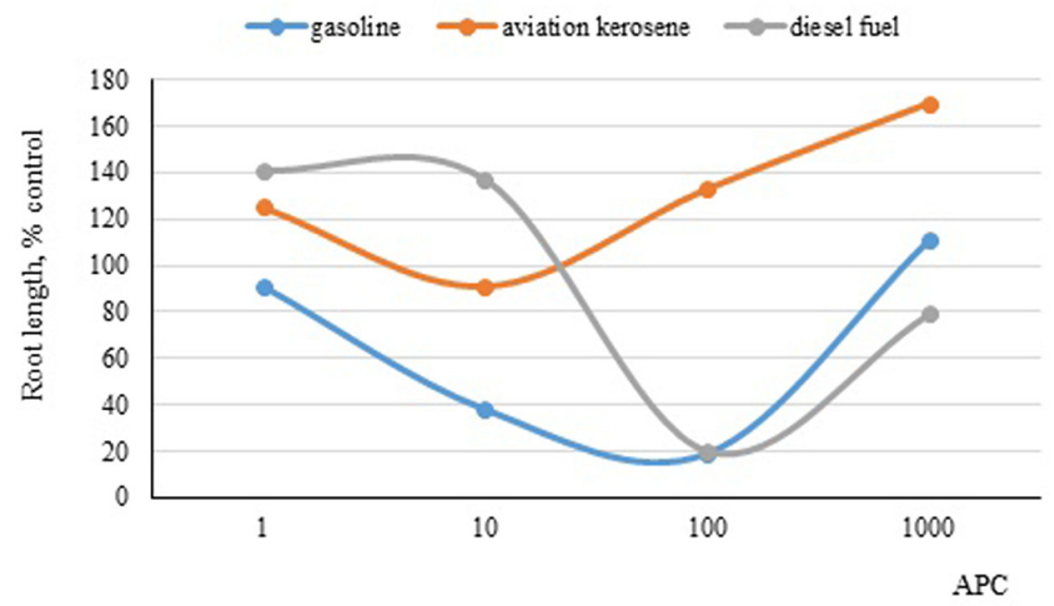

Figure 2. Dependence of the length of roots of three-day seedlings on the level of contamination with petroleum products

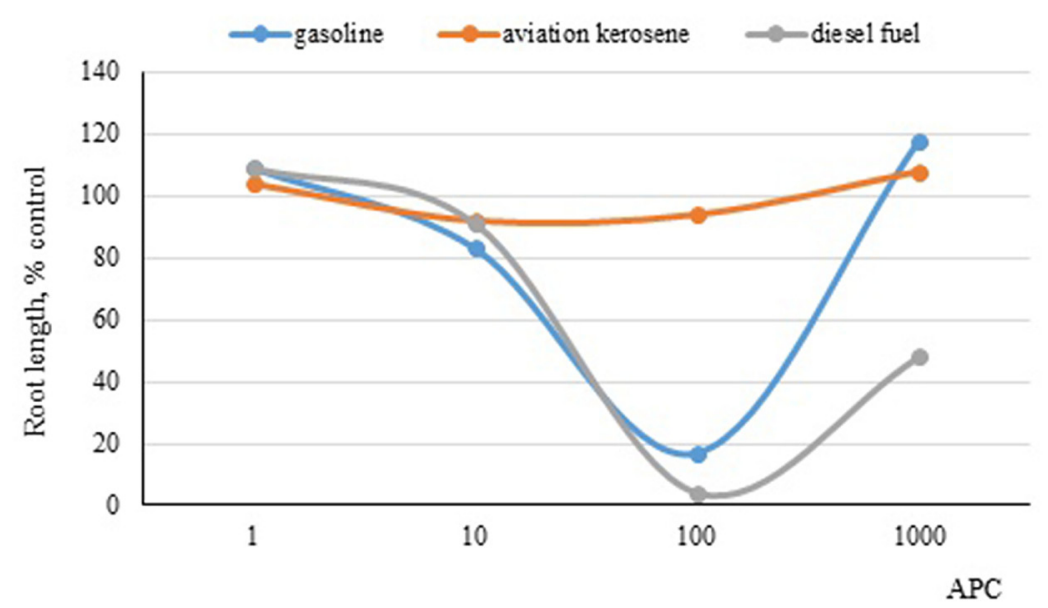

Figure 3. Dependence of the length of shoots of three-day seedlings on the level of oil pollution

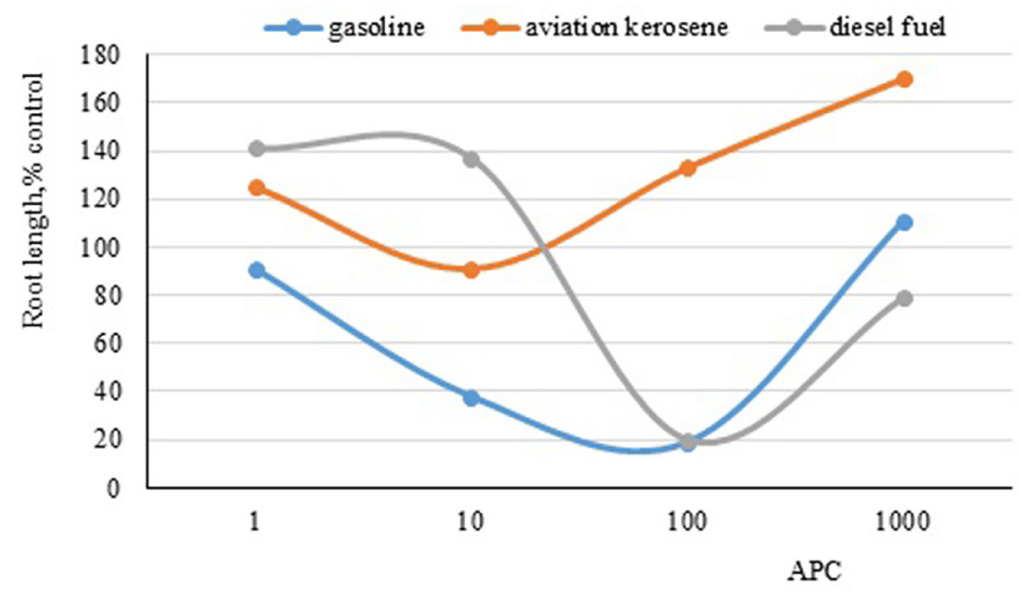

Figure 4. The dependence of the length of the roots of six-day seedlings on the level of contamination by petroleum products 


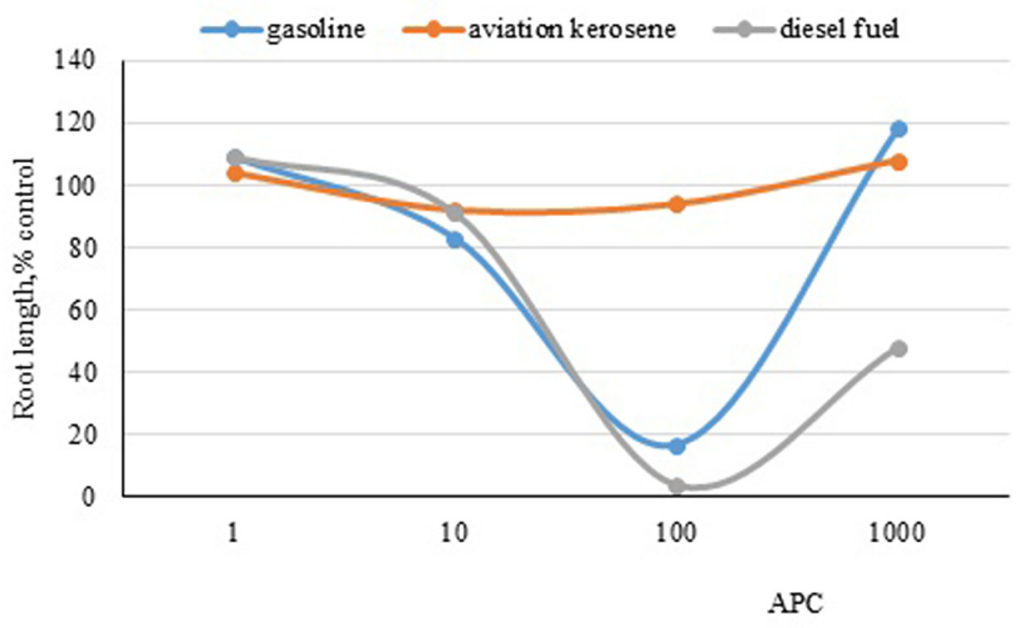

Figure 5. Dependence of shoot length of six-day-old seedlings on the level of oil pollution

effect on living organisms. Alkanes with a short hydrocarbon chain act especially quickly. These hydrocarbons are better soluble in water, easily pass into the cells of organisms through plasma membranes. It is believed that the direct toxic effect is determined by the light oil fractions that are part of light petroleum products. Due to the volatility and higher solubility of low molecular weight alkanes, their action is usually not longlasting. With a decrease in the content of light fraction, the toxicity of petroleum products is reduced, but the toxicity of aromatic compounds increases, the relative content of which increases, which, in its turn, may explain the inhibition of plant growth on the soil samples contaminated with aviation kerosene, at APC 1000. After all, among the investigated samples of oil products, aviation kerosene contains the smallest amount of aromatic hydrocarbons.

\section{CONCLUSIONS}

The possibility of studying the effect of petroleum products on plants directly in artificially contaminated soil has been confirmed. It has been established that when the soil is contaminated with oil products, aviation fuel has a greater impact on the shoots, whereas gasoline and diesel fuel have a lower impact on the root in lower concentrations. At higher concentrations, their depressant effect is almost equalized. Therefore, it is necessary to develop a maximum concentration limit for different brands of light petroleum products (motor gasoline, diesel fuel and aviation fuel), because at the same concentrations in artificially contaminated soil, a different level of phytotoxicity is observed.

\section{REFERENCES}

1. Anpilova Ye., Lukianova V., Trofymchuk O. 2020. Environmental safety of motor Transport enterprises within urban areas. Journal of Ecological Engineering, 21(4), 231-236.

2. Arystarkhova E.O. 2017. Conceptual aspects of improving the system of ecological monitoring of surface waters. Ahroekolohichnyi zhurnal,1, 134-140 [in Ukrainian].

3. Danilov-Danilian V.I., Losev K.S. 2014. Environmental challenge and sustainable development. Progress-Traditsiya, Moskva [in Russion].

4. Han G., Cui B.X., Zhang X.X., Li K.R. 2016. The effects of petroleum-contaminated soil on photosynthesis of Amorpha fruticosa seedlings. International Journal of Environmental Science and Technology, 13, 2383-2392.

5. Hussain I., Puschenreiter M., Gerhard S., Sani S., Khan W.U., Reichenauer T.G. 2019. Differentiation between physical and chemical effects of oil presence in freshly spiked soil during rhizoremediation trial. Environmental science and pollution research, 18 (26), 18451-18464.

6. Iatsyk A.V. 2007. Methods of calculating anthropogenic load and classification of ecological status of small river basins of Ukraine. Ukrainskyi naukovodoslidnyi instytut vodohospodarsko-ekolohichnykh problem, Kyiv [in Ukrainian].

7. Isaienko V.M., Madzhd S.M., Pysanko Ya.I., Nikolaiev K.D., Bovsunovskyi E.O., Cherniak L.M. 2019. Development of a procedure for determining the basic parameter of aquatic ecosystems functioning - environmental capacity. Eastern-European 
Journal of Enterprise Technologies, 1/10 (97), 21-28.

8. Kozulia T.V., Yemelianova D.I. 2017. Information and algorithmic support for comprehensive environmental assessment of system facilities. Systemni doslidzhennia ta informatsiini tekhnolohii, 2, 68-76 [in Ukrainian].

9. Lim M.W., Lau E.V., Poh P.E.: Mar. Pollut. Bull. 2016. A comprehensive guide of remediation technologies for oil contaminated soil - Present works and future directions. 1 (109), 14-45.

10. Madzhd S.M. 2013. Bioassay techniques of ecological status assessment near the airports. Proceedings of the National Aviation University, 4 (57), 111-115.

11. Madzhd S.M. 2019. Development of scientific bases of the basin principle of management of ecological safety of technogenic transformed surface water objects: dys. na zdobuttia nauk. stupenia doktora. tekhn. nauk: 21.06.01. Kyiv [in Ukrainian].

12. Madzhd S.M., Kulynych Ya.I. 2017. Science methodology for the assessment of ecologically unsafe conditions of the function of technogenic-changing water systems. Visnyk Kremenchutskoho natsionalnoho universytetu, 4 (105), 88-95 [in Ukrainian].

13. Mylarshchikov A.M. 2012. Systematization of methods for assessing anthropogenic impact on the environment. Internet-zhurnal "Naukovedeniye", 3, 1-18 [in Russion].
14. Nakamura T. 2011. Ecosystem-based river basin management: its approach and policy-level application. Special Issue: Japan Society of Hydrology and Water Resources, 17 (14), 2711-272.

15. Obyhod H.O. 2016. Institutionalization of ecological security of Ukraine. Logos, Kyiv [in Ukrainian].

16. Radomska M., Cherniak L., Horobtsov I., Kolotylo O. 2018. Sustainable Development of the urban agglomeration through the creation of an urban network of protected areas: case study of Kyiv city urban ecosystem. Studia Periegetica, 4(24), 59-75.

17. Radomska M.M., Madzhd S.M., Cherniak L.M., Mikhyeyev O.M. 2020. Environmental pollution in the airport impact area - case study of the Boryspil international airport. Ecologycal Problems, 2 (5), 76-82.

18. Shevchyk L., Romaniuk O. 2017. The analysis of biological ways of restoration of the oil contaminated soils. Sciencerise: Biological Science, 1 (4), 31-39.

19. Sukhariev S.M., Chudak S.Iu., Sukhareva O.Iu. 2016. Fundamentals of ecology and environmental protection. Tsentr navchalnoi literatury, Kyiv [in Ukrainian].

20. Udod V.M., Madzhd S.M., Kulynych Ya.I. 2017. Regional features of structural and functional organization of development of technogenic changed aquatic ecosystems. Visnyk Kremenchutskoho natsionalnoho universytetu, 3 (104), 93-99 [in Ukrainian]. 